\title{
STAPHYLOCOCCUS AUREUS COLONIZATION ON AN ERYTHRODERMIC PSORIASIS PATIENT
}

\author{
Dave Gerald Oenarta $^{1)}$, NN Sri Budayanti ${ }^{2)}$, NN Dwi Fatmawati ${ }^{2)}$, NM Adi Tarini ${ }^{2)}$
}

\begin{abstract}
Skin plays an important role as the physical barrier and first-line immunological defense against dangerous stimuli, including bacteria. Erythroderma is a condition of excessive skin irritation causing extensive erythema and desquamation. Erythroderma itself is caused by various underlying conditions, one of them is psoriasis vulgaris. In erythroderma, there is an extensive disruption of physical barrier leading to the exposure of various bacteria, including Staphylococcus aureus. In human, this bacteria can either colonize or infect the host if exposed to open wound. It is essential to determine this as it will affect the necessity of administering antibiotics. Laboratory examinations such as complete blood count, Gram staining, and culture can help to determine the status of this bacteria. A correlation between clinical features and laboratory examinations is paramount in deciding patient management.
\end{abstract}

Keywords: Staphylococcus Aureus, Erythroderma, Physical Barrier, Colonization, Pathogen.

\begin{abstract}
ABSTRAK
Kulit memainkan peranan yang penting sebagai sawar fisik dan pertahanan lini pertama terhadap stimulus berbahaya, termasuk bakteri. Eritroderma merupakan sebuah kondisi iritasi kulit yang berlebihan yang menyebabkan eritema dan deskuamasi yang luas. Eritroderma disebabkan oleh berbagai kondisi yang mendasari, salah satunya psoriasis vulgaris. Kerusakan sawar fisik yang luas pada eritroderma menyebabkan kulit terpapar oleh berbagai bakteri, termasuk Staphylococcus aureus. Paparan bakteri ini pada luka dapat menyebabkan kolonsasi atau infeksi pada hospes. Menentukan status bakteri sebagai patogen atau kolonisasi sangat penting terkait dengan keperluan pemberian antibiotika. Pemeriksaan laboratorium seperti darah lengkap, pewarnaan Gram, dan kultur dapat membantu menentukan hal ini. Sebuah korelasi antara gambaran klinis dan pemeriksaan laboratorium sangat penting dalam menentukan penatalaksanaan pasien.
\end{abstract}

Kata Kunci: Staphylococcus Aureus, Eritroderma, Sawar Fisik, Kolonisasi, Patogen 
1) Department of Dermatology and Venereology, Faculty of Medicine, Widya Mandala Catholic University, Surabaya. 2) Department of Clinical Microbiology, Faculty of Medicine, Udayana University, Sanglah General Academic Hospital, Denpasar

\section{INTRODUCTION}

Skin is a physical barrier and first-line immunological defense against dangerous stimuli. The outermost layer of the skin hinders the entrance of pathogens. Low water level, certain skin acidity, and normal floras on the epidermis form the physical barrier which can prevent the entrance of pathogen. ${ }^{1}$

Erythroderma refers to exaggerated skin irritation which causes extensive erythema and desquamation involving at least $>90 \%$ of the body surface area. ${ }^{2,3}$

The certain incidence rate of erythroderma is challenging to obtain as a majority of reports are retrospectives, and do not mention the overall incidence rate. A large scale retrospective study from India reported an incidence rate of 35 in every 100,000 cases in dermatology outpatients. An analysis of 138 erythrodermic patients found that $75 \%$ of sufferers were blacks, $22.5 \%$ Indians, and $2.5 \%$ whites and more commonly found in HIV patients. In terms of sex, males were found to be more commonly affected than females with the ratio of $2 \cdot 3: 1 .^{2}$

Staphylococcus aureus is a Grampositive bacteria which can be commensal or pathogen in human. S. aureus acquired from external sources can become infectious if exposed to open wounds. Generally, patients become infected after this bacteria colonized their skin or mucosa. The mucosal areas commonly colonized by this bacteria are nose, throat, vaginal wall, dan gastrointestinal tract. ${ }^{4}$

We report an erythrodermic psoriasis case on a 48-year old female. This case will hopefully increase our understanding about the change in the patient's skin barrier and its relation to the $S$. aureus colonization found in the culture. Determining $S$. aureus as a pathogen or merely a colonizer will also be discussed as a base to decide whether antibiotics are necessary or not.

\section{CASE}

A 48-year old Indonesian female came to the outpatient clinic with the chief complaint of redness and scales all over her body.

Anamnesis revealed that this complaint started approximately one week before the patient came, initially presented as small red spots which quickly became generalized and scaly. The scales were found 
to become thicker. The patient also complained of fever and itch.

The patient was previously complaining of the same condition one year ago and he was also repeatedly hospitalized for this condition. The patient was diagnosed as erythroderma caused by psoriasis vulgaris. He was instructed to come to the outpatients for check-ups, however since three weeks ago, he had been absent from his regular check-ups and did not consume his medication. When consulted to the dental and oral health clinic, he was found to be suffering from gangrene radix. He was advised to undergo teeth extraction however he had not yet done it. His condition made him feel stressful but he refused hospitalization on his previous visit, and was given oral methylprednisolone, oral loratadine, oral folic acid, topical desoxymethasone, and urea.

Physical examination showed that the patient was compos mentis, with heart rate of 85 times/minute, respiratory rate of 20 times/minute, and a core temperature of $37.5^{\circ} \mathrm{C}$. The general status was within normal limits.

Dermatology status on his face, chest, both arms and legs showed diffuse erythematous macules covered with thick white scales, multiple well-circumscribed linear erosions were also seen with various sizes from 1 x $0.5-1 \times 0.8 \mathrm{~cm}$ (Figure 1). Diascopy examination revealed pale areas.
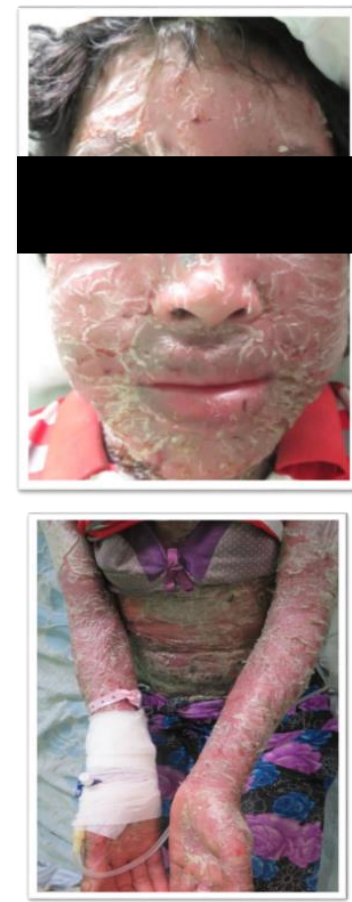
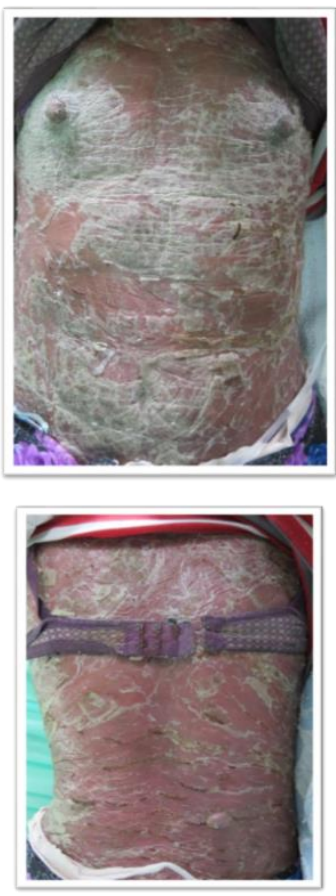
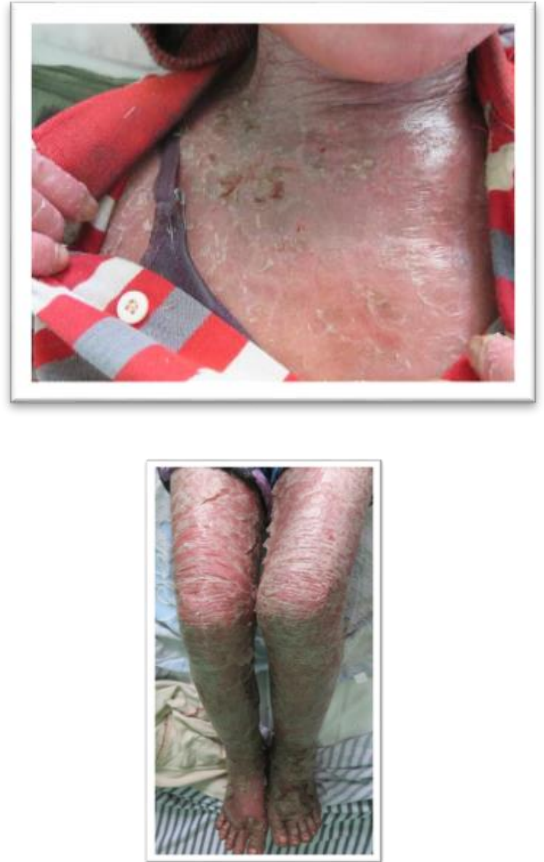

Figure 1. Physical examination on the patient showed diffuse erythematous macules covered with thick white scales, some erosions can also be seen. 
Complete blood count (CBC) showed leukocytosis $(20.5 \mathrm{~K} / \mu \mathrm{L}$ in the range of $4.1-$ $11 \mathrm{~K} / \mu \mathrm{L})$, normal neutrophil (60\% within the range of $47-80 \%)$, and eosinophilia $(15.8 \%$ in the range of $0-5 \%$ ); while there were leukocyturia, proteinuria, ketonuria, and urobilinogenuria on his urinalysis.

The patient was diagnosed as erythrodermic psoriasis. He was hospitalized and given intravenous $0.9 \% \mathrm{NaCl}$, threetimes-weekly $2.5 \mathrm{mg}$ oral methotrexate with 12-hour interval, $8 \mathrm{mg}$ oral methylprednisolone thrice daily, once daily folic acid, and twice daily $2.5 \%$ hydrocortisone ointment and olive oil.

A wound base swab was performed for bacterial culture, and Staphylococcus aureus was isolated (Figure 2). Gram examination revealed $1+$ coccus bacteria. It was concluded that the isolated $S$. aureus was a colonizer, so treatment with antibiotics was not recommended.
On the $8^{\text {th }}$ day of hospitalization, complaints of fever, redness, scales, and itch had subsided. General status and vital signs were all within normal limits. The patient's dermatology status showed that some erythematous macules had become hyperpigmented with small erosions were still visible. The diagnosis was still the same. Methotrexate was stopped. However, other medications were continued

\section{DISCUSSION}

Erythroderma is a severe form of dermatitis showing widespread erythema and desquamation involving $>90 \%$ of the body surface area. Psoriasis vulgaris and atopic dermatitis are considered the two most common causes of erythroderma. It is known that trauma, infections, drugs such as lithium, antimalarials, co-trimoxazole, environmental hazards, psychological stress, and metabolic abnormalities are all able to trigger psoriasis and erythroderma. ${ }^{6}$

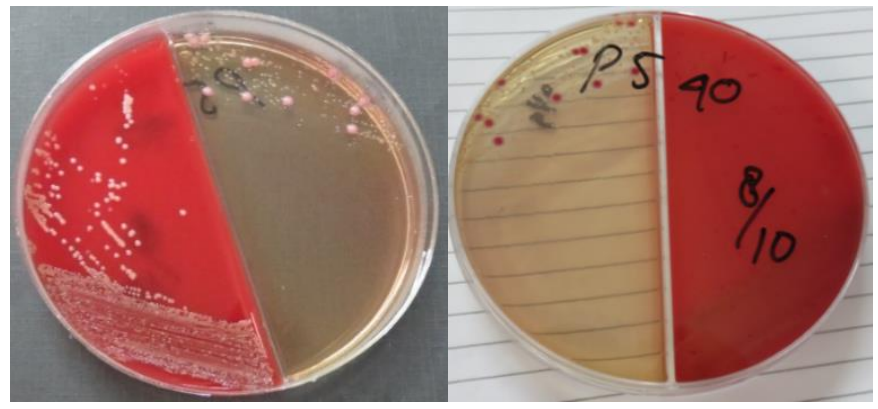

Figure 2. The colonies of Staphylococcus aureus were observed on bi-plate agar (blood agar and MacConkey agar). 

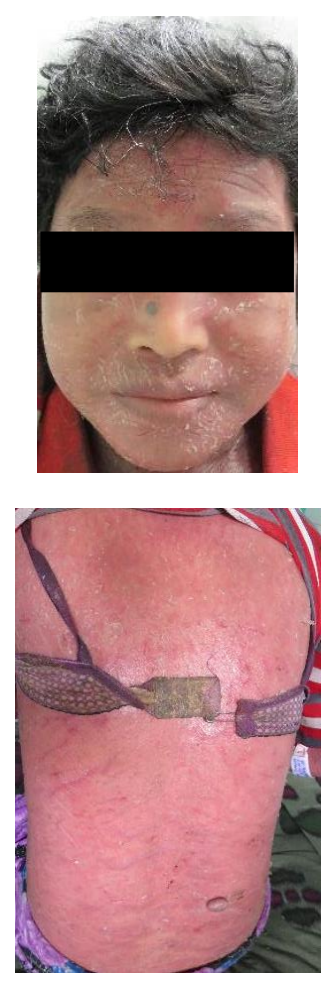
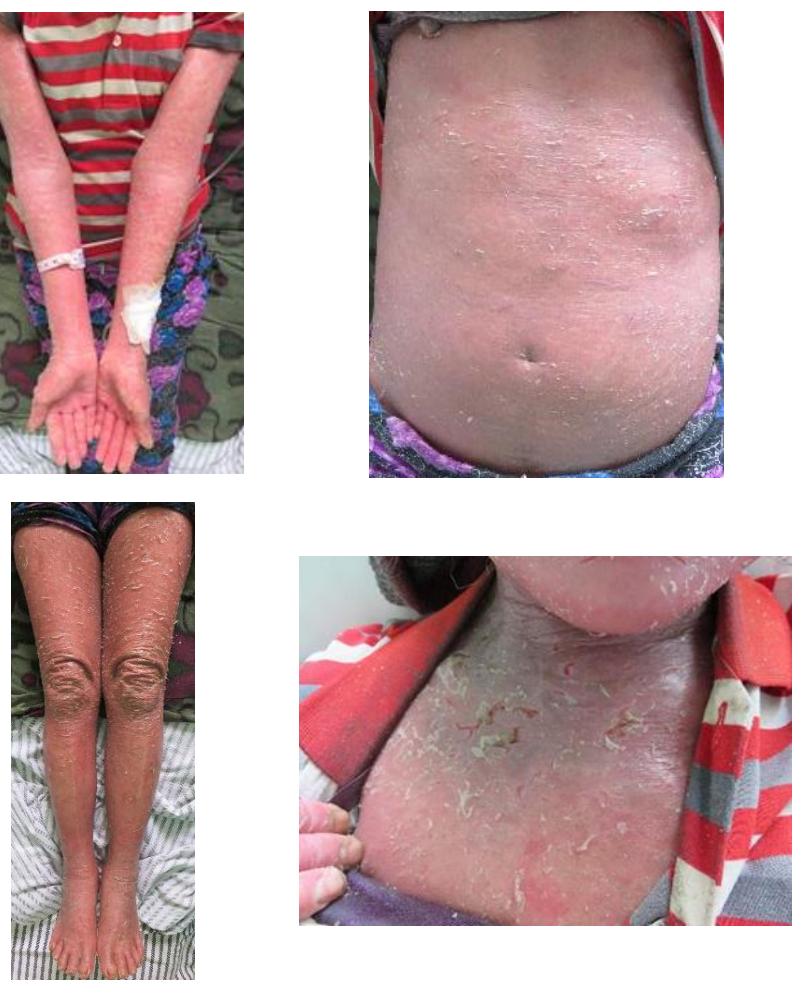

Figure 3. Physical examination on day 8 showed clinical improvements.

Systemic manifestations of erythroderma are fever, dehydration, malaise, and malnutrition. ${ }^{5}$

In this case, the patient was diagnosed as erythrodermic psoriasis based on his corresponding clinical manifestations as well as his medical history. Approximately 52\% of erythrodermic patients have one or more focal infection(s). This can worsen and may lead to the development of toxic shock syndrome (TSS); hence identification of this focal infection and other specific laboratory examinations need to be performed to predict the development of hemodynamic problems. Secondary infections, dehydration, electrolyte imbalance, body temperature dysregulation, and high-output cardiac failure are potential complications. ${ }^{3,7}$ T-cell activation is believed to play an important role in the pathogenesis of psoriasis. There are several case reports which concluded that bacterial infections could trigger psoriasis, and S. aureus was isolated from the patients. Carriage sites may also contaminate. It is also found that peripheral mononuclear blood cells in active psoriasis develop a significantly higher proliferative response to Staphylococcal enterotoxin B compared to healthy subjects. Skin resolution is related to the reduction of lymphocyte response. 
Erythroderma can accompany atopic dermatitis, drug eruption, psoriasis vulgaris, secondarily after cutaneous T-cell lymphoma (CTCL) or even idiopathic. Enterotoxin superantigen-laden $S$. aureus is commonly found in patients with CTCL especially in the erythrodermic CTCL. Based on these facts, it can be concluded that bacterias with geneencoding toxins can stimulate T-helper cells with the toxins acting as superantigens that can worsen erythroderma. ${ }^{8,9}$

In this case, the patient was subfebrile $\left(37.5^{\circ} \mathrm{C}\right)$ which then became febrile $\left(38.5^{\circ} \mathrm{C}\right)$. Leukocytosis was found on his CBC.

Staphylococcus organisms which are commonly infectious are skin surface and mucosal colonizer. It is known that there is a carrier state in the general population which can transform into an infectious state once the bacteria gets the access to the normally sterile sites through trauma or abrasion on the skin surface or mucosa. However, at many times, due to the minor nature, this trauma incident goes unnoticed. This bacteria can also be transmitted from one person to another. During transmission, this organism can become part of the normal flora which is then becomes exposed to the sterile sites through trauma or other invasive procedures, such as during emergency procedures or surgery. ${ }^{9,10}$
In this case, multiple erosions in his whole body found in the physical examination serves as the suspected port of entry for the bacteria leading to the secondary infection. Wound base culture and gram examination were performed on the erosions at the chest. Gram examination showed scanty leukocytes, 1+ coccus, scanty epithelial cells, and no gram-negative bacteria was found. The patient's culture showed Staphylococcus aureus as a colonizer. Antibiotics are not recommended in this case.

S. aureus is known as a highly virulent bacteria; thus, confirmation is needed to ascertain its role as a pathogen or a colonizer to decide the necessity of antibiotics. Based on the clinical symptoms, the patient was subfebrile. Fever is an inflammatory process with various triggers, infections, or non-infection. In erythroderma, a complex interaction between proinflammatory cytokines and chemokines contributes to the development of fever. To support the decision, a comparison needs to be made between the bacteriological and the blood count results to see the leukocytes and neutrophils. Bacterial examination in this patient showed scanty epithelial and leukocytes, 1+ gram-positive coccus, and no gram-negative bacterias. On his blood count, 
leukocytosis $(20.5 \mathrm{~K} / \mu \mathrm{L})$ was found with the neutrophils still within the normal value of $60 \%$. Leukocytosis can be observed in both inflammation or infection. The patient was diagnosed with erythrodermic psoriasis as his underlying condition, which contributed to the inflammatory state seen in this patient. The presence of secondary infection is confirmed by the neutrophil value, where the value of $60 \%$ meant the patient was not neutrophilic, hence this result was a marker of an immunological process instead of an infection. The result of the Gram examination further supported the assessment of an colonization or contamination instead of a real infection. The combination of clinical and laboratory examinations showed that the S. aureus did not need to be treated with antibiotics as it was a colonizer or a contaminant in the patient.

To colonize their hosts, the microorganisms need to be able to bind themselves to the flat cornified keratinocytes. Microbial-specific adhesin contributes to the strong binding to prevent the bacteria from falling off during the desquamation. Teichoic acid, a non-protein adhesin, plays an important role during the early phase of the colonization, while the microbial surface contains the microbial surface components recognizing adhesive matrix molecules
(MSCRAMMs) IsdA and ClfB which are more critical for both colonization and persistence. $^{9-11}$

To be able to bind to the epidermis, Staphylococcus spp is faced with the challenge of retaining colonization from the threat of antimicrobial defense mechanism. Anionic and cationic anti-microbial peptide (cAMP) together with lysozymes and RNAses form the first line immunological defense. Epithelial cells produce two main classes of cAMP, which are defensins and cathelicidins. Their reservoirs are located in the bottom part of the skin, due to the calcium gradient on human epidermis which supports the function of kallikrein, the enzyme that processes the cathelicidins on a differentiating epidermis. Cathelicidins are secreted from sweat glands, where they are active in a very low concentration during a low $\mathrm{pH}$ and hypersalinity condition. Defensins and cathelicidins are amphipathic peptides which are bound to the negatively charged cell membrane of the Staphylococcus spp with electrostatic interaction. Chains of peptide aggregation cause channel formation which affects membrane permeability. Dermicidin inhibits RNA and protein synthesis. Its mechanism depends on the formation of ion channel on the bacterial membrane stabilized by zinc. 
Lysozyme is located on body fluids, and its production and secretion are maintained by the epithelial cells. Some staphylococcal species are resistant to the activity of lysozyme and $\mathrm{N}$-acetylmuramoylhydrolase including $S$. aureus, $S$. epidermidis, $S$. xylosus, and S. lugdunensis. This resistance play an essential role to the skin colonization. ${ }^{9-11}$

S. aureus produces exoprotein fattyacid modifying enzyme (FAME) and esterified fat with cholesterol or alcohol to reduce the cellular toxicity. FAME activity is inhibited by triglycerides and diglycerides; thus, the majority of Staphylococcus spp isolated from the skin has lipase activity. Lipase hydrolyzes triglycerides and diglycerides releasing free fatty acids as the substrate for FAME. ${ }^{12}$

The main end product of epidermal differentiation is ceramide, an amide-linked fatty acid, and sphingoid base, which can form as sphingosine, phytosphingosine, dihydrosphingosine, and hydroxysphingosine to produce 16 isomers. Ceramide, which forms more than $50 \%$ of stratum corneum fat, plays a significant role as a skin barrier. S. aureus can be quickly eliminated by sphingosine. ${ }^{9}$

Arginine catabolic mobile element (ACME) which encodes the activity of arginine deiminase is found in various Staphylococcus spp. ACME genes which are well-characterized are oligopeptide permease operon (opp) and arc operon, which are bacterial virulence genes. Bacterial defense and growth are limited by the low relative humidity (RH) and high salinity which produce osmotic stress. $S$. aureus can grow in a low RH environment. Tolerance to dessication is essential to bacterial transmission, and it can affect its defense if $\mathrm{RH}$ falls below the growth threshold. The ability of Staphylococcus spp to produce polysaccharide intracellular adhesin (PIA) contributes to the tolerance to desiccation. PIA is thought to act similarly like the exopolysaccharide (EPS) of Pseudomonas aeruginosa. EPS inhibits the water loss to increase the time for bacterial adaptation. Cardiolipin (CL) contributes to the osmotic stress resistance and catalyzes the conversion of peptidoglycan to CL and glycerol. ${ }^{9-11}$

\section{CONCLUSION}

We have reported a case of Staphylococcus aureus colonization on an erythrodermic psoriasis patient. This diagnosis was based on clinicopathologic and laboratory examinations. CBC examination showed leukocytosis without neutrophilia. Gram examinations showed the presence of Gram-positive coccus together with sparse 
leukocyte and epithelium. S. aureus was found during the bacterial culture from the wound base. Based on the clinical and laboratory correlation, it can be concluded that the bacteria was a colonizer, not an infectious agent.

\section{DAFTAR PUSTAKA}

1. Alonzo, F., Torres, V.J., 2013. A Lesson in Survival: S. aureus versus the Skin. Cell Host Microbe 13, this issue, p 3-5.

2. Sehgal, V.N., Srivastava,G., Sardana, K. 2004. Erythroderma/exfoliative dermatitis: a synopsis. International Journal of Dermatology (43) p 39-47.

3. Umar, S.H., Elston,D.M., 2014. Erythroderma (Generalized Exfoliative Dermatitis).Available on: http://emedicine.medscape.com/article/1 106906-overview. Accessed: $28^{\text {th }}$ October 2015.

4. Liu, G.Y., 2009. Molecular Pathogenesis of Staphylococcus aureus Infection. Pediatr Res 65 (5 pt 2) p 71-77.

5. Zattra, E., Fortina, A.B., Peserico, A., 2012. Erythroderma in the era of biological therapies. Eur J Dermatol 22: (2), p167-71.

6. Teran, C.G.; Teran, C.N.; Balderrama, C. 2010. A severe case of erythrodermic psoriasis associated with advanced nail and joint manifestations: a case report.
Journal of Medical Case Reports 4:1794:(179) p 1-3.

7. Byer, R.L; Bachur, R.G. 2006. Clinical deterioration among patients with fever and erythroderma. Pediatrics (6) p 24502460.

8. Zuel-Fakkar, N.M., El-Shokry,M.H. 2010. Study of Erythroderma and Psoriasis Exacerbation by Staphylococcal Superantigens. J Egypt Women Dermatol Soc 7: p 123 - 128.

9. Coates, R., Moran, J., Horsburgh, M.J., 2014. Staphylococci: colonizers and pathogens of human skin. Future Microbiol. 9(1) : p 75-91

10. Forbes, B.A., Sahm, D.F., Weissfeld, A.S., $2007 . \quad$ Staphylococcus, Micrococcus, and similar organism, In: Bailey \& Scott's Diagnostic Microbiology. $12^{\text {th }}$ ed. Missouri: Mosby Elsevier:p 254-263.

11. Otto, M., 2010. Staphylococcus colonization of the skin and antimicrobial peptides. Expert Rev Dermatol 5(2): 183-195

12. Tong, S.Y.C, Davis, J.S; Eichenberger, E.; Holland, T.L.; Fowler, V.G. 2015. Staphylococcus aureus Infections: Epidemiology, Pathophysiology, Clinical Manifestations, and Management. Clin Microbiol Rev (28) p 603-635. 